\title{
A Survey Based Investigation for Cloud Computing Adoption Internationally
}

\author{
Raja Muhammad Ubaid Ullah ${ }^{\# 1}$, Dr.Kevan A. Buckley ${ }^{\# 2}$,Dr. Mary Garvey ${ }^{\# 3}$, Dr. Jun Li ${ }^{\# 4}$. \\ School of Mathematics and Computer Science \\ University of Wolverhampton, Wulfruna Street, Wolverhampton WVI ILY, UK.
}

\begin{abstract}
Cloud computing (CC) is a new trend in information technology and has the potential to play a major role, in addressing inefficient resources, make a fundamental growth and competitiveness for large, small and medium enterprises (SMEs) internationally. The main benefits of adoption of CC services by Large and SMEs will be able to use the latest technology, without the need for the upfront cost, but reducing cost, providing a secure information platform and increasing productivity. The main drawback is that most organisations are adopting the CC without properly understanding that information data they are storing in the cloud is secure or not. The primary objective of this paper is to explore the CC adoption from large and SME perspective internationally. The current state of CC information intensity, different levels of external and other support in the organisations, motivations, requirements prevent the intensity of information and various level of external and other support for CC environment, the study findings can provide guidance on how to address the business and technology risks associated by CC adoption. However, a survey is conducted internationally on 107 Large and SMEs through survey monkey website, which shows interest in the CC services adoption. Specifically, in this paper users are evaluated through 6 factors, for instance, external support, competitive pressure, senior management support, employees cloud knowledge, adequate resources and information intensity.Though survey it is revealed that already adopted some cloud services are $84.11 \%$, are in the processes of Implementing $8.41 \%$, intend to adopt cloud services in the next 3 years $6.54 \%$ and don't intend to adopt any cloud services in near future $0.93 \%$. The findings are expected to be beneficial for Large and SMEs in their adoption of CC services and may also be useful for service providers with respect to end-users' concerns.
\end{abstract}

Keywords - Cloud Computing, Cloud Computing adoption, cost effective Cloud, SMEs

\section{INTRODUCTION}

The rapid evolvement of new technology in the modern business market boosts competition to the highest level, as result products and skills have become obsolete [1]. Due to limited resources, some businesses and organisations have less advantage in such a competition. This has restricted access to new technologies of IT services for some companies [11]. Companies play a vital role in economies by offerings a large amount of employment [9]. In order to survive, companies need to find new strategic ideas and implement at a faster pace to achieve a competitive advantage over their challengers within the global market. "The need to quickly respond to business demands is imperative in this new age. Waiting six to eight weeks for a new server deployment is unacceptable" [10]. The appropriate use of Information and Communication Technologies (ICT) helps businesses and organisation to become more efficient [13]. Whereas, CC is actually a model for delivering information services that really provides flexible use of servers, scalability and the management of the services [12]. A new strategy should enable Large and SMEs to incorporate new technologies for the intensity of information, develop process innovation and enhance the speed at various level of supporting factors for CC adoption. A developed IT infrastructure can remove some of the barriers to global competition and allow Large and SMEs to be more efficient, competitive and also provide a degree of flexibility.

As $\mathrm{CC}$ is a new trend in information technology and has the potential to play a major role, in addressing inefficient resources and make a fundamental growth and competitiveness for Large and SMEs throughout the world. The main benefits of adoption of CC services by Large and SMEs will be able to use the latest technology, without the need of upfront cost, but reducing cost, providing secure information platform and increasing productivity. CC also offers a new way to business and faster time support to market by offering ready-to consume cloud-enabled resources, for instance, IT infrastructure as a service, software platforms and business applications. All these services can be accessed on demand and provide support to according businesses requirement far faster than acquiring, installing, configuring and operating IT services resources in the house [14]. 
$\mathrm{CC}$ has been used by the millions of people in different manifestations, such as free emails (e.g., Yahoo Mail and Gmail, etc.) and also free office productivity applications (e.g., Google Apps). The organisations are benefitted by the technology and its various unique features, such as high availability, elastic scalability, less complexity, speed, agility, flexibility and the economic advantage [19]. CC facilitate the organisations by delivering resources and respective services by a user-pay system through the Internet [2]. CC basically offers a new business solution, which enables the organisations to rent the required information technology (IT) infrastructure, respective platforms and the software through positioning their business applications and their data storage in the cloud environment. There are a couple of well-known cloud examples which include Amazon, Google and Microsoft (Department of Finance and Deregulation (DFD)), [15].

The good number of research on $\mathrm{CC}$ has concentrated on several issues related to $\mathrm{CC}$ adoption. However, still difficulties exist in deciding on the approach of CC adoption services for Large and SMEs. Particularly to assist SMEs with respect to adopt CC services, the aim of this study is to answer some selected research questions: when considering to adopt or already adopted the $\mathrm{CC}$ services. This paper discusses the outcome of a survey conducted with 107 Large and SMEs worldwide through survey monkey web site. The study has found that Large and SMEs are quite interested in CC services due to the reduction in cost, flexibility and scalability of IT resources that the $\mathrm{CC}$ services offer. But, the study also shows that organisations have also concerns about information intensity with respect to the adoption of $\mathrm{CC}$.

\section{WHAT IS CLOUD COMPUTING?}

In an October, 2009 presentation titled [3, Chapter 1 - p.2, 90] "Effectively and Securely Using the CC Paradigm," by Peter Mell and Tim Grance of the National Institute of Standards and Technology (NIST) Information Technology Laboratory, CC is defined as follows:

Cloud computing is a model for enabling ubiquitous, convenient, on-demand network access to a shared pool of configurable and reliable computing resources (e.g., networks, servers, storage, applications, services) that can be rapidly provisioned and released with minimal consumer management effort or service provider interaction.

Another definition [5, p.3] by using virtualized computing and storage resources and modern Web technologies, CC provides scalable, network-centric, abstracted IT infrastructures, platforms and applications as on-demand services. These services are billed on a usage basis.

A usually CC definition quoted was established by the National Institute of Standards and Technology (NIST) in the U.S. [6]. It specifies five essential characteristics of $\mathrm{CC}$.

The five essential characteristics of all cloud services provided by the NIST definition, the characteristics are $[6$, p.2]:

- On-demand self-service: A Services can be provided unilaterally and on demand to consumers, such as server time and network storage, without requiring human interaction $[7,16]$.

- Broad network access: Services that are available over the network in real-time through standard mechanisms (e.g., mobile phones, tablets, laptops and workstations) [16].

- Resource pooling:The computing resources are pooled to provide parallel service provision to using multi-tenant model [17], while being adjusted to the each user actual demand. Examples of resources include storage, processing, memory and network bandwidth [16].

- Rapid elasticity: Resources capabilities are rapidly provisioned and released in various [17], fine-grained quantities outward and inward so that the systems can be scaled as required. To the consumer, the resources appear to be unlimited [16].

- Measured quality of service: The services leverage a quantitative and qualitative metering capability (e.g., storage, processing, bandwidth and active user accounts), so that usage-based billing and validation of the service quality are possible [16].

"CC represents a shift away from computing as a product that is purchased, to computing as a service that is delivered to consumers over the Internet from large-scale data centres or "clouds" [19, p.1]. This remote service [18, Chapter 1 - p. 3] "can be defined as a new style of computing in which dynamically scalable and often virtualized resources are provided as a services over the Internet.

\section{HISTORY OF CLOUD COMPUTING}

The concept of CC was first introduced in 1950. For academia and corporation use large scale mainframes was accessible during that time to perform activities. As the mainframes were too costly and practically it was not possible to have separate mainframes for each user; therefore a new 
architecture was developed and introduced. The new architecture enables the users to access the mainframe and share the CPU time and power from different terminals. This new architect attracts users, which result increased the return on investment and decreased the mainframes' idle (inactive) time. This phenomenon got more popular later, in the 1960s after John McCarthy [20] started to claim that someday computation will become a public utility. With the passage of time nowadays this idea gains more popularity than ever. As like other types of utility (water, electricity, gas and telephony), in near future, many believe that the basic level of computing will be provided to people to meet their day to day activities [20].

Below mentioned is the history of CC $[22,23]$ :

In 1959 the John McCarthy computer scientist initiates the first project a time-sharing system use, which enable several people to use at the same time a single, central, computer.

In 1969 another computer scientist J. C. R. Licklider, developed the direct predecessor to the internet called ARPANET (Advanced Research Projects Agency Network). His new perception was to interconnect and access programmes and data at any site for everyone, (somewhat like CC).

In early 1970s full time-sharing solutions were available on platforms as Multics (on GE hardware), Cambridge CTSS and the earliest UNIX ports (on DEC hardware).

In 1990 virtual private network, (VPN) services begin to offer by telecommunications companies, enabling the businesses to send and receive their data across shared or public networks, because their computing devices were directly connected to the private network.

In INFORMS Annual Meeting, Dallas, TX, October 26-29, 1997 the academic usage and definition of the first known term of the new computing paradigm, CC appears to be provided by Prof. Chellappa in a talk titled Intermediaries in Cloud-Computing [21].

He suggested that this would be a new "computing paradigm where the boundaries of computing will be determined by economic rationale rather than technical limits alone."

Amazon Web Service was introduced in 2002 by Amazon.com; this service enables customers to store their respective data and provide a facility to many people to work on the same task. Social networking website Facebook was launched in 2004.
In 2006 Amazon's Elastic Compute Cloud (EC2) was launched, which providing facility to users run their application on cloud. First introduced by Amazon's Simple Storage Service (S3) the pay-as-you-go model of payment which is now the standard for CC [24].

In 2007, Platform-as-a-Service was launched by Salesforce.com [24].

In 2008 NASA's OpenNebula, enhanced in the RESERVOIR by European Commission funded project and therefore became the first to deploying open-source software for private and hybrid clouds and for the federation of clouds [24].

In April 2008, Google released Google App Engine in beta [24].

In 2009, Google Apps was launched, for users to create and store their documents online [24].

Salesforce.com in 2010, launched his cloud-based database which allowed customers to develop applications on cloud. These developed application can be used by any device, written on any language and same run on any platform.

In February 2010, Microsoft released Microsoft Azure, which was announced in October 2008 [24].

In July 2010, Rackspace Hosting and NASA jointly launched an open-source cloud-software initiative known as OpenStack. The OpenStack project intended to help organizations offering cloudcomputing services running on standard hardware. The early code came from NASA's Nebula platform as well as from Rackspace's Cloud Files platform [24].

On March 1, 2011, IBM announced the IBM Smart Cloud framework to support Smarter Planet. Among the various components of the Smarter Computing foundation, $\mathrm{CC}$ is a critical part [24].

In May 2012, Google Compute Engine was released in preview, before being rolled out into General Availability in December 2013 [24].

On June 7, 2012, Oracle announced the Oracle Cloud. This cloud offering is poised to be the first to provide users with access to an integrated set of IT solutions, including the Applications Software-as-aService (SaaS), Platform-as-a-Service (PaaS) and Infrastructure-as-a-Service (IaaS) layers [24].

\section{PRIMARY DATA COLLECTION METHODOLOGY}

\section{A. Survey}

The research based on the survey "provides a quantitative or numeric description of trends, 
attitudes, or opinions of a population by studying a sample of that population. It includes cross-sectional studies using questionnaires for data collection, with the intent of generalizing from a sample to a population" [27]. The usual strategy is linked to a quantitative approach, although it may be used in qualitative research [25]. Even it is used to answer questions of the different form: such as "who, what, where, how much and how many" [25, p. 144]. This method is used because it permits the researcher to economically collect a large amount of data from a sample of a population [25]. Data collection technique is based on a questionnaire that is generally used in quantitative research [26]. Apart from that other techniques, it includes structured observations and structured interviews [25]. Use of such techniques in a survey, the data collected in a crosssectional study can be specific to a population. To consider the survey data as standard, which is easy for comparison as well as comprehension [25]. The collected data from the population representative is analysed to test and establish relationships between variables [27].

\section{B. Survey Design}

In this study the best method described are surveys to collect the actual data in a population that is actually too large to perceive directly [29]. Generally the surveys help the researcher to understand and generalize their required results on a population by asking a sample questions [28]. In this study surveys method chosen over the other methods, because this can be simple and in this particular case where the objective is just to identify solutions, practices and guidelines for the adoption of CC services that has no alleviation strategies, surveys provide a better chance in reaching large population. Three types of surveys are reported [29, 30] and as follow:

- Needs assessment survey: to ask for problems and gather possible solutions.

- Marketing survey: surveys to understand the demand and the nature of specific programs.

- Evaluation surveys: to evaluate the outcome of newly implemented programs and policies.

In this study the assessment type is chosen to gather possible solutions, practices and guidelines. The source of medium used to communicate with the particular respondents is using e-mail service and the responses are collected thoroughly using an online survey tool.

\section{Survey Administration}

In this research, the plan is to adopt the method of an electronic survey. For this purpose, plan to utilise the services of survey monkey and also send the email which contains a brief introduction about the survey to the targeted population. Plan to keep the survey open as much to obtain the desired number of required results. The survey starts with the initial information about the respondent and the rest is based on Likert type question about the different research.

The designated questionnaire is used for a collection of primary research data. The primary research data collection was carried out through a survey is used for the collection of research data for using CC adoption services by large and SME's.

\section{Survey Data Collection}

The survey link was be created at (www.surveymonkey.com) and questionnaires were distributed. The survey link is kept active to gather as many responses as possible that can suggest alleviation strategies. The survey link is also a onetime response link which assures that there won't be multiple responses from the same person (this avoids duplication) and this can improve the quality of surveys.As methodology was based on online survey approach and the targeted population was IT users internationally. 173 Participants from my LinkedIn contracts and over 150 participants were invited through emails from IT organisations of different sizes and business sectors internationally. A 107 completed survey results were received in 5 months' time period, response rate is approximately $33 \%$ which is satisfactory for this type of study.

\section{SURVEY DATA ANALYSIS.}

\section{A. Survey Respondents}

Table 1 and 2 shows a summary of cloud and IT job experience results of respondents internationally. The survey aim was to obtain the indepth view from the IT professional, IT experts users, which representing different sectors of the IT that allow the study aims to access both tacit and explicit knowledge of experts in the organisations. 107 IT experts participated in the survey with a different organisational background. The respondents were requested to state the cloud and IT experience, all the respondents have cloud and IT experience respectively apart from one participant who has no cloud experience, but has 24 years of IT experience. Survey results show that minimum cloud experience of the respondents only one have zero experience in the cloud, whereas rest all have cloud experience minimum one year and a maximum of 13 years. Whereas, the job experience of the respondents shows that minimum experience is 4 years and a maximum of 34 years of job experience in IT.

Table 1 especially shows the cloud experience summary of respondent's year wise. The respondents experience in cloud is categories in three categories; $0-4,5-8$ and $9-13$ years. The top of the table are 
respondents with $0-4$ years of experience in the cloud are $60(56.07 \%)$. In second position $5-8$ years of experience in the cloud had $45(42.06 \%)$ respondents. Finally at third position $9-13$ years of cloud experience only $2(1.87 \%)$ respondents. The summary shows that respondents mostly have good numbers of experience in the cloud who responded survey, this will reflect the authenticity of the survey result.

Table 1: Respondents by Cloud Experience Year Wise Summary.

\begin{tabular}{|c|c|c|}
\hline $\begin{array}{l}\text { Cloud Experience in } \\
\text { Years }\end{array}$ & $\begin{array}{l}\text { Experience in } \\
\text { No. of Years }\end{array}$ & $\%$ \\
\hline 0 - 4 Year Exp. & 60 & $56.07 \%$ \\
\hline $4 \quad 8$ Year Exp. & 45 & $42.06 \%$ \\
\hline 9-13 Year Exp. & 2 & $1.87 \%$ \\
\hline Total --> & 107 & $100.00 \%$ \\
\hline
\end{tabular}

Table 2 shows the overall IT job experience summary of respondent's year wise. The respondents experience in IT is categories in four categories; 0-10, 11-20, 21-30 and 31-40 years. The top of the table are respondents with $11-20$ years of experience in the IT sector are $70(65.42 \%)$. In second position $0-10$ years of experience in the IT sector had $31(28.97 \%)$ respondents. In third position $21-40$ years of experience in the IT sector have only $4(3.74 \%)$ respondents, which bit low. Finally at the bottom of the table are $31-40$ years of IT sector experience, which are only $2(1.87 \%)$ respondents. This summary shows that respondents mostly have good numbers of experience in the IT sector also who responded survey, this will reflect the authenticity and reliability of the survey result.

Table 2: Participantsby Job Experience Year Wise Summary.

\begin{tabular}{|c|c|c|}
\hline $\begin{array}{l}\text { IT Job Experience } \\
\text { in Years }\end{array}$ & $\begin{array}{l}\text { Experience in } \\
\text { No. of Years }\end{array}$ & $\%$ \\
\hline 0 - 10 Year Exp. & 31 & $28.97 \%$ \\
\hline 11-20 Year Exp. & 70 & $65.42 \%$ \\
\hline 21-30 Year Exp. & 4 & $3.74 \%$ \\
\hline 31-40 Year Exp. & 2 & $1.87 \%$ \\
\hline Total --> & 107 & $100.00 \%$ \\
\hline
\end{tabular}

\section{B. Participants by their job title.}

The 107 participants of a survey show in Table 3 belong to a different part of the organisation according to their different nature of job and figure 1 shows the graphical representation. Top of the table is IT Manager with $16(14.95 \%)$, followed by IT consultant with $13(12.15 \%)$ and on the third position IT Specialist with 8 (7.48\%). Whereas, Project Manager and Software Engineer made a contribution with $5(4.67 \%)$ each one participated. Interestingly IT
Coordinator, IT Director, System Analyst and System Support Manager with 4 (3.74\%) each one participated. On the other hand System Engineer, Assistant Support Manager and System Support Engineer with $2(1.87 \%)$ each one participated. Finally very low number of $\mathrm{AD}, \mathrm{AM}, \mathrm{BDD}, \mathrm{BDE}$, CEO, CIM B2B, CSA, Cyber SA, DA, DM, IT Head, IT SA, IT SM, IT SE, LSA, MIS, MO IT, MQA, MSS, Network Architecture, Operations Lead, Oracle DBA, Product Specialist, SID, Senior Manager Data and Analytics, Solutions Manager, SSE, SSM and Telecom Consultant with 1 (0.93\%) each one participated respectively.

A good percentage of executive, middle-level management and technical staff participated in the survey from different size and sectors of the organisations. But, the low percentage of the participant also includes decision makers, middle management and technical staff from different size and sectors of the organisations and show their interest in CC adoption. Which reflect that $\mathrm{CC}$ is still on-going and more organisations are using $\mathrm{CC}$ services and benefited from them. The participant's cross section shows the level of their reliability of the survey results and on the other hand, also provides inputs for the design of the roadmap.

Table 3: Participantsby job title.

\begin{tabular}{|c|c|c|}
\hline Designations & $\begin{array}{c}\text { No of } \\
\text { Respondents }\end{array}$ & $\%$ \\
\hline IT Manager & 16 & $14.95 \%$ \\
\hline IT Consultant & 13 & $12.15 \%$ \\
\hline IT Specialist & 8 & $7.48 \%$ \\
\hline Project Manager & 5 & $4.67 \%$ \\
\hline Software Engineer & 5 & $4.67 \%$ \\
\hline IT Coordinator & 4 & $3.74 \%$ \\
\hline IT Director & 4 & $3.74 \%$ \\
\hline System Analyst & 4 & $3.74 \%$ \\
\hline System Support Manager & 4 & $3.74 \%$ \\
\hline IT Support Engineer & 3 & $2.80 \%$ \\
\hline IT Support Specialist & 3 & $2.80 \%$ \\
\hline $\begin{array}{l}\text { System Solution } \\
\text { Manager }\end{array}$ & 3 & $2.80 \%$ \\
\hline System Engineer & 2 & $1.87 \%$ \\
\hline $\begin{array}{l}\text { Assistant Support } \\
\text { Manager }\end{array}$ & 2 & $1.87 \%$ \\
\hline $\begin{array}{l}\text { System Support } \\
\text { Engineer }\end{array}$ & 2 & $1.87 \%$ \\
\hline $\begin{array}{l}\text { Application Developer } \\
\text { (AD) }\end{array}$ & 1 & $0.93 \%$ \\
\hline Assistant Manager (AM) & 1 & $0.93 \%$ \\
\hline $\begin{array}{l}\text { Business Development } \\
\text { Director (BDR) }\end{array}$ & 1 & $0.93 \%$ \\
\hline $\begin{array}{l}\text { Business Development } \\
\text { Executive (BDE) }\end{array}$ & 1 & $0.93 \%$ \\
\hline CEO & 1 & $0.93 \%$ \\
\hline Client Integration & 1 & $0.93 \%$ \\
\hline
\end{tabular}




\begin{tabular}{|c|c|c|}
\hline $\begin{array}{l}\text { Manager B2B (CIM) } \\
\text { B2B }\end{array}$ & & \\
\hline $\begin{array}{l}\text { Computer System } \\
\text { Analyst (CSA) }\end{array}$ & 1 & $0.93 \%$ \\
\hline $\begin{array}{l}\text { Cyber Security Analyst } \\
\text { (Cyber SA) }\end{array}$ & 1 & $0.93 \%$ \\
\hline $\begin{array}{l}\text { Database Administrator } \\
\text { (DA) }\end{array}$ & 1 & $0.93 \%$ \\
\hline $\begin{array}{l}\text { Development Manager } \\
(\mathrm{DM})\end{array}$ & 1 & $0.93 \%$ \\
\hline IT Head & 1 & $0.93 \%$ \\
\hline $\begin{array}{l}\text { IT Security Analyst (IT } \\
\text { SA) }\end{array}$ & 1 & $0.93 \%$ \\
\hline $\begin{array}{l}\text { IT Support Manager (IT } \\
\text { SM) }\end{array}$ & 1 & $0.93 \%$ \\
\hline $\begin{array}{l}\text { IT Systems Engineer (IT } \\
\text { SE) }\end{array}$ & 1 & $0.93 \%$ \\
\hline $\begin{array}{l}\text { Lead System Analyst } \\
\text { (LSA) }\end{array}$ & 1 & $0.93 \%$ \\
\hline $\begin{array}{l}\text { Manager Information } \\
\text { System (MIS) }\end{array}$ & 1 & $0.93 \%$ \\
\hline $\begin{array}{l}\text { Manager Operation IT } \\
(\text { MO IT) }\end{array}$ & 1 & $0.93 \%$ \\
\hline $\begin{array}{l}\text { Manager Quality } \\
\text { Assurance (MQA) }\end{array}$ & 1 & $0.93 \%$ \\
\hline $\begin{array}{l}\text { Manager System Support } \\
\text { (MSS) }\end{array}$ & 1 & $0.93 \%$ \\
\hline Network Architecture & 1 & $0.93 \%$ \\
\hline Operations Lead & 1 & $0.93 \%$ \\
\hline Oracle DBA & 1 & $0.93 \%$ \\
\hline Product Specialist & 1 & $0.93 \%$ \\
\hline $\begin{array}{l}\text { Senior Infrastructure } \\
\text { Developer (SID) }\end{array}$ & 1 & $0.93 \%$ \\
\hline $\begin{array}{l}\text { Senior Manager, Data } \\
\text { and Analytics }\end{array}$ & 1 & $0.93 \%$ \\
\hline Solutions Manager & 1 & $0.93 \%$ \\
\hline $\begin{array}{l}\text { System Solutions } \\
\text { Engineer (SSE) }\end{array}$ & 1 & $0.93 \%$ \\
\hline $\begin{array}{l}\text { Systems Support } \\
\text { Manager (SSM) }\end{array}$ & 1 & $0.93 \%$ \\
\hline Telecom Consultant & 1 & $0.93 \%$ \\
\hline Total --> & 107 & $100.00 \%$ \\
\hline
\end{tabular}

\section{Company Status about CC Services Usage.}

In Table 4 survey results shows that top of the table are organisations who already adopted some cloud services $90(84.11 \%)$, on the second position are those who are in the processes of implementing 9 $(8.41 \%)$. Whereas, on third position those are intended to adopt cloud services in the next 3 years 7 (6.54\%), very low number are those who don't intend to adopt any cloud services $1(0.93 \%)$ and interestingly zero response from another category. As a high number of participation from those who already using some cloud services, which reflect that participant contribution is meaningful.

Table 4: Company Status about CC Services Usage.

\begin{tabular}{|l|c|c|}
\hline \multicolumn{1}{|c|}{ Company Status } & No. & \% \\
\hline $\begin{array}{l}\text { We have already adopted some } \\
\text { cloud services }\end{array}$ & 90 & $84.11 \%$ \\
\hline $\begin{array}{l}\text { Are in the processes of } \\
\text { Implementing }\end{array}$ & 9 & $8.41 \%$ \\
\hline $\begin{array}{l}\text { We intend to adopt cloud services } \\
\text { in the next 3 years }\end{array}$ & 7 & $6.54 \%$ \\
\hline $\begin{array}{l}\text { We don't intend to adopt any } \\
\text { cloud services in near future }\end{array}$ & 1 & $0.93 \%$ \\
\hline Other (please specify) & 0 & $0.00 \%$ \\
\hline
\end{tabular}

\section{Scope of Respondents Organisation.}

Surveys results reveal a good number of participation from different sectors of the organisation internationally. At first position, the national level of organisations participated with 78 (72.90\%). Whereas, in the second position multinational level of organisations are participating with 29 (27.10). Those who don't know about their scope of organisation are zero in number. The survey results reflect that more interest is at the national level as compared to the multinational organisation.

Table 5: Scope of Organisations.

\begin{tabular}{|l|c|c|}
\hline Organisation Scope & $\begin{array}{c}\text { No. of } \\
\text { Organisations }\end{array}$ & $\mathbf{\%}$ \\
\hline National & 78 & $72.90 \%$ \\
\hline Multinational & 29 & $27.10 \%$ \\
\hline Don't Know & 0 & $0.00 \%$ \\
\hline Total $\rightarrow$ & 107 & $100 \%$ \\
\hline
\end{tabular}

\section{E. Respondents Organisation size.}

The size of the Organisation is a major factor in the acceptance indicator for the adoption of any new technology. Table 6 shows the data collected from a survey with respect to respondents Organisation size. This survey is divided into five different sizes of organisation employee's strength category; less than $20,20-100,100-1000$, above 1000 and not sure. A total of 107 responses collected in which $20-100$ are top of the table with 37 $(34.58 \%)$ responses. In the second position of the table, the category is $10-1000$ with $32(29.91 \%)$ responses. The third position on the table is above than 1000 with $23(21.50 \%)$ responses. The less than 20 categories responded 15 (14.02\%). More
Figure 1: Graph representation of survey respondents by job titles. 
encouraging is that category not sure have $0(0.00 \%)$ response.

The survey results reflect that SMEs and large all sizes of organisations participated in the survey with good numbers, which shows that $\mathrm{CC}$ adoption is still ongoing in a different type of businesses. The results also show that SMEs and large organisation adopted or plan to adopt cloud services, whereas SMEs have still more intrigued in CC adoption. A SMEs possibly be more benefitted, because they have a lack of resources to build their own in-house IT services infrastructure. SMEs could be benefited with cloud offered high quality IT services at a low cost. But, on the other hand, the interest of the large organisations shows that they also benefited with low cost and high quality of cloud services. This study also shows that technology innovation does clash with the size of the organisation, sooner or later all organisations will face CC adoption.

Table 6: Staff Employed by respondent Organisations.

\begin{tabular}{|c|c|c|}
\hline $\begin{array}{c}\text { No of Employee's } \\
\text { Category }\end{array}$ & $\begin{array}{c}\text { No. of } \\
\text { Responses }\end{array}$ & \% \\
\hline $20-100$ & 37 & $34.58 \%$ \\
\hline $100-1000$ & 32 & $29.91 \%$ \\
\hline Above than 1000 & 23 & $21.50 \%$ \\
\hline Less than 20 & 15 & $14.02 \%$ \\
\hline Not sure & 0 & $0.00 \%$ \\
\hline Total $\rightarrow$ & 107 & $100.00 \%$ \\
\hline
\end{tabular}

\section{F. External Support}

The factor external support in this study is defined that organisations need any support from external sources to use CC services successfully. To understand the phenomena three questions are inquired in the survey questionnaire.

Question 1: Organisations must ensure that they have adequate technical support before adopting CC; 62 respondents agree that they have support before adopting $\mathrm{CC}$, while 24 respondents strongly agree on it. Whereas 10 respondents disagree on it, 6 respondents neutral in this regards and finally 5 strongly disagree with this.

Question 2: Organisations must ensure that they have adequate technical support after adopting CC;74 respondents agree that they have support after adopting $\mathrm{CC}$, while 26 respondents strongly agree on it. Whereas4 respondents neutral on it and 3 respondents strongly disagree and zero disagree with this.

Question 3: Organisations have to provide staff training from cloud providers and other training institutions; 73 respondents agree that they have support before adopting $\mathrm{CC}$, while 20 respondents strongly agree on it. Whereas 11 respondents neutral on it and 1 respondent each is disagreed and strongly disagree with this respectively.

\begin{tabular}{|c|c|c|c|c|c|}
\hline Questions & $\begin{array}{l}\text { Strongly } \\
\text { Disagree }\end{array}$ & Disagree & Neutral & Agree & $\begin{array}{l}\text { Strongly } \\
\text { Agree }\end{array}$ \\
\hline $\begin{array}{l}\text { Organisations must ensure that they have adequate technical } \\
\text { support before adopting CC. }\end{array}$ & 5 & 10 & 6 & 62 & 24 \\
\hline $\begin{array}{l}\text { Organisations must ensure that they have adequate technical } \\
\text { support after adopting CC. }\end{array}$ & 3 & 0 & 4 & 74 & 26 \\
\hline $\begin{array}{l}\text { Organisations have to provide staff training from cloud } \\
\text { providers or other training institutions. }\end{array}$ & 1 & 1 & 11 & 73 & 20 \\
\hline
\end{tabular}

\section{G. Competitive pressure}

Competitive pressure refers to "the level of pressure felt by the firm from competitors within the industry" [204, p. 1341]. [205] stated that competitive pressure is very influential in the adoption of technology. By using two questions in the survey try to investigate whether competitive pressure influences CC adoption.

Question 1: Organisations encounter pressure from competitors to adopt CC technology? 54 respondents agree that they encounter pressure from competitors to adopting $\mathrm{CC}$, while 10 respondents strongly agree on it. Whereas 22 respondents disagree on it, 16 respondents neutral in this regards and finally 5 strongly disagree with this.

Question 2: CC technology helps organisation gain an competitive edge? 80 respondents agree that organisation gains a competitive edge with $\mathrm{CC}$, while 17 respondents strongly agree on it. Whereas 6 respondents neutral on it, 3 respondents disagree in this regards and finally,only 1 strongly disagree with this.

\begin{tabular}{|l|r|r|r|r|}
\hline Questions & $\begin{array}{l}\text { Strongly } \\
\text { Disagree }\end{array}$ & Disagree & Neutral & $\begin{array}{l}\text { Strongly } \\
\text { Agree }\end{array}$ \\
\hline $\begin{array}{l}\text { Organisations encounter pressure from competitors to } \\
\text { adopt CC technology? }\end{array}$ & 5 & 22 & 16 & 54 \\
\hline $\begin{array}{l}\text { CC technology helps organisation gain an competitive } \\
\text { edge? }\end{array}$ & 1 & 3 & 10 \\
\hline
\end{tabular}




\section{H. Senior Management Support}

Senior management support refers to the decision makers that are also key to the successful integration of new technological innovation in organisations that influence the adoption of innovation [145]. Hence, the following questions are developed in the context of $\mathrm{CC}$ for the survey.

Question 1: Senior management is involved in reviewing $C C$ consultant's recommendations;86 respondents agree that senior management involved, while 15 respondents strongly agree on it. Whereas 5 respondents neutral on it, 1 respondent strongly disagrees in this regards and finally zero disagree with this.

Question 2: Senior management has a role to play in $t^{*}$ he monitoring of $\mathrm{CC}$ adoption projects;89respondents agree that senior management has a role to play in $\mathrm{CC}$ adoption projects, while 15 respondents strongly agree on it. Whereas2 respondents neutral on it, 1 respondent is strongly disagreed and zero disagree with this.

Question 3: Senior management support is needed to ensure that the resources needed to adopt a technology or to expand its use, are available;interestingly for this question, 63 respondents strongly agree that senior management support in this respect is very important, while 43 respondents agree on it. Whereas only 1 respondent is disagreed on it and with respect to strongly disagree and neutral zero response on this regard each with this respectively

\begin{tabular}{|l|r|r|r|r|r|}
\hline Questions & $\begin{array}{l}\text { Strongly } \\
\text { Disagre }\end{array}$ & Disagree & Neutral & Agree & $\begin{array}{l}\text { Strongly } \\
\text { Agree }\end{array}$ \\
\hline $\begin{array}{l}\text { Senior management is involved in reviewing CC } \\
\text { consultant's recommendations. }\end{array}$ & 1 & 0 & 5 & 86 & 15 \\
\hline $\begin{array}{l}\text { Senior management has a role to play in the monitoring of } \\
\text { CC adoption projects. }\end{array}$ & 1 & 0 & 2 & 89 & 15 \\
\hline $\begin{array}{l}\text { Senior management support is needed to ensure that the } \\
\text { resources needed to adopt a technology or to expand its use, } \\
\text { are available. }\end{array}$ & 0 & & 1 & & \\
\hline
\end{tabular}

\section{Employees Cloud Knowledge}

Employee's knowledge or experience about $\mathrm{CC}$ technology is not directly measured. The CC adoption rate is directly interrelated to levels of skills and expertise about CC according to [183]. In the context three questions have been developed for a survey:

Question 1: Organisations should be concerned about the lack of cloud knowledge or expertise; 57 respondents agree that organisations should be concerned lack of cloud knowledge or expertise, while 21 respondents strongly agree on it. Interestingly 14 respondents neutral and disagree each respectively on it and only 1 respondent has strongly disagreed in this regards.

\begin{tabular}{|c|c|c|c|c|c|}
\hline Questions & $\begin{array}{l}\text { Strongly } \\
\text { Disagree }\end{array}$ & Disagree & Neutral & Agree & $\begin{array}{l}\text { Strongly } \\
\text { Agree }\end{array}$ \\
\hline $\begin{array}{l}\text { Organisations should be concerned about the lack of } \\
\text { cloud knowledge or expertise. }\end{array}$ & 1 & 14 & 14 & 57 & 21 \\
\hline Staff need to be trained in order to use the CC. & 0 & 2 & 8 & 68 & 29 \\
\hline $\begin{array}{l}\text { Organisations should create staff awareness of using } \\
\text { CC. }\end{array}$ & 0 & 0 & 4 & 77 & 26 \\
\hline
\end{tabular}

\section{J. Adequate Resources}

The Adequate resources basically refer to the resources which are needed for the adoption of CC [145]. As concern with adequate resources only two questions have been developed for a survey:

Question 1: Organisations should have enough resources to provide speed and reliable Internet for $C C ; 54$ respondents agree that organisations should
Question 2: Staff need to be trained in order to use the $C C ; 68$ respondents agree that staff needs to be trained, while 29 respondents strongly agree on it. Whereas 8 respondents neutral on it, 2 respondents disagree and zero disagree with this.

Question 3: Organisations should create staff awareness of using $C C ; 77$ respondents agree that organisations should create staff awareness about CC, while 26 respondents strongly agree on it. Whereas only 4 respondent neutral on it and with respect to strongly disagree and disagree zero response on this regard each with this respectively. provide high speed and reliable Internet for $\mathrm{CC}$, whereas very close to agreeing 51 respondents strongly agree on it. Only 1 respondentfrom neutral and strongly disagree each respectively on it and zero disagree in this regards.

Question 2: Organisations should have an adequate budget for CC adoption; with regard to an adequate budget, 69 respondents agree, while 34 respondents 
strongly agree on it. Whereas, 3 respondents neutral on it, only 1 respondent is strongly disagreed and zero disagree with this. This will reflect that adopting this new technology budget is also play an important role.

\begin{tabular}{|c|c|c|c|c|c|}
\hline Questions & $\begin{array}{l}\text { Strongly } \\
\text { Disagree }\end{array}$ & Disagree & Neutral & Agree & Strongly Agree \\
\hline $\begin{array}{l}\text { Organisations should have enough resources to } \\
\text { provide high speed and reliable Internet for CC. }\end{array}$ & 1 & 0 & 1 & 54 & 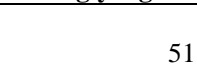 \\
\hline $\begin{array}{l}\text { Organisations should have an adequate budget for } \\
\text { CC adoption. }\end{array}$ & 1 & 0 & 3 & 69 & 34 \\
\hline
\end{tabular}

\section{K. Information Intensity}

The information intensity is defined as "the degree to which information is present in the product or service of a business" [67]. Therefore following questions are related to this construct:

Question 1: Organisations should have fast information access, whenever and wherever they need; 67 respondents agree that organisations should have fast information access, whenever and wherever they really need. While 37 respondents strongly agree on it. 2 respondents disagree on it, only 1 respondent is neutral in this regards and zero strongly disagree on it.
Question 2:Organisations should have reliable, relevant and accurate information; as regards to the reliability, relevancy and accuracy of the information 79 respondents agree, while 23 respondents strongly agree on it. Whereas, 3 respondents neutral on it, 1 respondent is disagreed and strongly disagree each respectively in this regard.

Question 3: Organisations should have up-to-date information all the time; with regards to up-to-date information, all the time high response of 80 respondents are agreeing, while 18 respondents strongly agree on it. Whereas, 7 respondent neutral on it, 2 respondents disagree on it and zero respond as strongly disagree on it.

\begin{tabular}{|c|c|c|c|c|c|}
\hline Questions & $\begin{array}{l}\text { Strongly } \\
\text { Disagree }\end{array}$ & Disagree & Neutral & Agree & $\begin{array}{l}\text { Strongly } \\
\text { Agree }\end{array}$ \\
\hline $\begin{array}{l}\text { Organisations should have fast information access, } \\
\text { whenever \& wherever they need. }\end{array}$ & 0 & 2 & 1 & 67 & 37 \\
\hline $\begin{array}{l}\text { Organisations should have reliable, relevant and } \\
\text { accurate information. }\end{array}$ & 1 & 1 & 3 & 79 & 23 \\
\hline $\begin{array}{l}\text { Organisations should have up-to-date information all } \\
\text { the time. }\end{array}$ & 0 & 2 & 7 & 80 & 18 \\
\hline
\end{tabular}

\section{DISCUSSION ON FINDINGS}

The main objective of this research is to evaluate different factors affecting CC adoption internationally. Try to achieve the objective of this research by using a quantitative technique with the use of an online survey. The finding of the research will be discussed in relation to the research objective.

Objective 1: To investigate the respondents experience about the cloud and IT job experience in different organisations and sectors internationally in CC. The survey results revealed that a large number of respondents have $0-4$ years such $56.07 \%$ have cloud experience, whereas 5-8 years of cloud experience of the respondents are $42.06 \%$. On the hand respondents IT job experience was divided into four categories of IT experience. The respondents with $0-10$ years of IT experience are $28.97 \%$, encouraging the number of respondents are from $11-20$ years of experience in IT. Whereas $21-30$ years of experience in IT $3.74 \%$ people participated and with $31-40$ years of IT experience only $1.87 \%$ of people have participated.
Most respondents are those who already using different types of CC services, which shows that they have cloud services experience. In survey participants from executive/middle management and technical staff involvement from the national and multinational organisations and more importantly different sectors and sizes of organisations participations nationally and internationally will build confidence on results accuracy and reliability up to certain extents. The survey results revealed that respondents have some experience in the cloud and good experience in the IT fields also. They will understand the pros and cons of CC services and IT technology and their feedback really matter for this research.

Objective 2:To identify the external support for CC adoption a close-ended questionnaire been used in the survey. The survey results revealed that a good number of respondents in favour of the three areas, such as adequate technical support before adopting $\mathrm{CC}$, same adequate technical support after adopting $\mathrm{CC}$ and finally training of staff from CSP or other training institutions. The results show that adopting 
any new technology the success is based on the properly trained staff, which has an impact on the adoption of CC services technology.

As concern about the competitive pressure, the respondents have a mix response in this regards. To encounter pressure to adopt the CC technology respondents agree, but respondents still have some concern about this. But, gain a competitive edge response is completely another way around a good number of the respondent in favour of that and very few raise their concern. The survey result shows that competitive pressure has a low impact on the adoption of CC technology.

Concern about the senior management support survey results reveals that their involvement at all level has a positive impact on the adoption of this technology. As their better understanding of the new technology role, its importance, how it works and providing better resources for new technology the support of senior management is vital. Thus survey results show that senior management support plays an important role in the adoption of CC technology for the smooth running of the business day to day activities.

About employees cloud knowledge the respondent'smajority raised much concern about the lack of cloud knowledge or expertise. Also supported the staff training and create awareness about $\mathrm{CC}$ technology, which shows concern about the success of this technology. Survey results show that knowledge, expertise, training and awareness play an imperative role in using this technology and achieve business goals and objectives accordingly.

In view of adequate resources, the respondents are in favour that enough resources and adequate budget are on the priority of $\mathrm{CC}$ adoption technology. Which, help the organisation to cater the future difficulties to keep enjoying the benefits of this new technology without any hurdle on their day to day business activities. Survey results show that organisation should have resources and enough budget to adopt $\mathrm{CC}$ technology, which really cost-effective, save time and beneficial for business.

And finally information intensity, which is an important aspect of any organisation and plays a fundamental role. To adopting any technology with respect to information concern, certain issues must be addressed before utilising any service: such as fast information access, whenever and wherever they need, reliability, relevant, accurate information and finally up-to-date information all the time. For all these presently there is only one solution through CC which can provide, survey results show that respondents are in favour of $\mathrm{CC}$ adoption to enjoy these benefits.

\section{RECOMMENDATIONAND CONCLUSION}

Recommendation: In this section some areas of this research are briefly discussed, contribution to knowledge, future work and final conclusion of this study based on the research, therefore following recommendations are given for the growth of $\mathrm{CC}$ adoption.

a- The user must have a proper awareness by the cloud service providers (CSP's) and challenges, different types of external support, information security risks and benefits of $\mathrm{CC}$, for instance, what types of support required for adoption, how technology be best to utilise by employee and how they are benefited by $\mathrm{CC}$ services and CSP must give certain consideration for the $\mathrm{CC}$ services.

b- More CSP's availability will encourage the adoption process of CC in different sectors, especially in SMEs size organisations. They will really help to increase the proper awareness of $\mathrm{CC}$ and minimise the gap of certain issues related due to the wider geographical distance between $\mathrm{CC}$ resources and the respective consumers.

c- CSP's should emphasise on details briefing of CC services and provide a free trial of its services to clients for a stipulated period to encourage and build client confidence on $\mathrm{CC}$ services.

\section{CONTRIBUTION TO KNOWLEDGE}

The finding reveals that $\mathrm{CC}$ adoption will be the next generation requirement large and SMEs, especially for the SMEs size organisations. Which help them to carry out their day to day business tasks reliably, cost-effectively and with respect to secure information availability. The CC adoption process is still ongoing especially in SMEs size organisations, but some more work needs to be addressed in this sector to overcome the new issues and encourage more organisation to step up. Especially on primary services, concern about the easy access of data, basic infrastructure alliance were identified as the motivating factors for $\mathrm{CC}$ adoption.

The research shows that certain factors may affect the $\mathrm{CC}$ adoption process: such as not proper awareness of CC services, high cost of Internet bandwidth and especially unreliability of Internet services.

\section{FUTURE WORKS}

The outcome of this research will help to a certain extent by focusing on the future issues of $\mathrm{CC}$ adoption in different size and sector of organisations. Some current factors which are affecting CC adoption were analysed at a different aspect that will motivate the adoption process was stated in this study. There 
are some other factors about the $\mathrm{CC}$ adoption for future research should focus on identifying the extent of CC adoption.

\section{CONCLUSION}

There are a few core finding of the research. Generally, CC is not considered to be a marketing tool, but in reality it's a new technology that helps to change the way the business operation is run successfully. The benefit of $\mathrm{CC}$ resources readily available on demand, flexible, scalable and up-to-date information all the time whenever and wherever they need. The research shows that the $\mathrm{CC}$ is not a perception, but it's a next-generation tool used by all types of organisations to maximise their potential growth. The research reveals that still more SMEs and large organisation use this technology comfortably internationally.

The research shows that there is more need for persistent improvement in basic infrastructure and other related areas of the organisations to upgrade. For the meaningful utilisation of available basic infrastructure and proper awareness of $\mathrm{CC}$ are core necessities for more businesses sector to consider CC adoption in the near future. Whereas some factors need to be addressed such as expertise, staff training, availability, reliability and information intensity, otherwise adoption process slow down. Some organisations may have concern for $\mathrm{CC}$ adoption in a different part of the world with respect to not proper awareness and availability of appropriate adequate infrastructure, support and resources are the major determinant for $\mathrm{CC}$ adoption.

\section{REFERENCES}

[1] Book: Pauly, M. "T-Systems Cloud-Based Solutions for Business Applications," Cloud Computing: Principles and Paradigms (eds R. Buyya, J. Broberg and A. Goscinski), Chapter 11, page 299. John Wiley \& Sons, Inc., Hoboken, NJ, USA, January $3,2011$. http://mirror.thelifeofkenneth.com/sites/virtualpanic.com/ano nymousftplistings/ebooks/Cloud\%20Computing\%20Principl es\%20and\%20Paradigms.pdf

[2] Article: Factors That Influence Adoption of Cloud Computing: An Empirical Study of Australian SMEs. Authors Ishan Senarathna, Carla Wilkin, Matthew Warren, William Yeoh and Scott Salzman. Australasian Journal of Information Systems, 2018, Vol 22, Research Article. Australia.

http://journal.acs.org.au/index.php/ajis/article/download/1603 1832.pdf

[3] Book: Cloud Security: A Comprehensive Guide to Secure Cloud Computing - Authors: Ronald L. Krutz and Russell Dean Vines. Copyright (C) 2010 by Wiley Publishing, Inc., Indianapolis, Indiana. ISBN: 978-0-470-58987-8. Manufactured in the United States of America. http://www.itfront.cn/attachment.aspx?attachmentid=998

[4] International Conference: Organisational Factors Affecting Cloud Computing Adoption In Small And Medium Enterprises (SMEs) in service sector. Author Haslinda Hassan. CENTERIS - International Conference on ENTERprise Information Systems / ProjMAN - International Conference on Project MANagement / HCist - International
Conference on Health and Social Care Information Systems and Technologies, CENTERIS / ProjMAN / HCist 2017, 810 November 2017, Barcelona, Spain. Malaysia. https://reader.elsevier.com/reader/sd/pii/S1877050917323281 ?token=54A4BCECEA38D15ECD825B2246FACDC4EC6E 6A4967A6CA0C73B7AC327C9184BC958E9A6DFDA11A A93530B41E975D1745

[5] Book: Cloud Computing: Web Based Dynamic IT Services. Author: Baun, Christian, Publisher: Springer - Date 14-072011. https://epdf.tips/cloud-computing-web-based-dynamicit-services.html

[6] Journal: Cloud Computing And Security Issues In Cloud. Authors LalitDashora, Aditya Jain, Gaurav Savner, AshutoshPatidar and Virendra Singh. International Journal Of Research In Computer Applications And Robotics Issn 2320-7345. Vol.4 Issue 5, Pg.: 6-13 May 2016. India. http://www.ijrcar.com/Volume_4_Issue_5/v4i506.pdf

[7] Conference: Cloud Computing: Transforming Medium and High Tech Industries in Kenya. Authors Pauline W. Wanjiku and Christopher A. Moturi. IST-Africa 2016 Conference Proceedings Paul Cunningham and Miriam Cunningham (Eds) IIMC International Information Management Corporation, 2016 ISBN: 978-1-905824-54-0. Nairobi, Kenya. http://www.istafrica.org/Conference2016/outbox/ISTAfrica_Paper_ref_186 _8208.pdf

[8] Conceptual Paper: The Cloud Adoption Toolkit: Supporting Cloud Adoption Decisions in the Enterprise. Authors Ali Khajeh-Hosseini, David Greenwood, James W. Smith, Ian Sommerville, $11^{\text {th }}$ August 2010. United Kingdom. https://ifs.host.cs.st-

andrews.ac.uk/Research/Publications/Papers-PDF/2010/CloudAdoptionToolkit.pdf

[9] European Commission. "The New SME Definition: User Guide and Model Declaration. March 2005 https://ec.europa.eu/digital-single-market/en/news/new-smedefinition-user-guide-and-model-declaration

[10] Primus. "Cloud computing for SMEs: bandwagon or good business strategy?", 2011 . http://www.primustel.ca/en/business/news/articles/2011/2 011-09-22_Cloud-computing-for-SMEs.php

[11] Article: Determinants of Cloud Computing Adoption At Firm Level: From The Technological Context. Authors Haslinda Hassan and MohdHerryMohd Nasir. Journal of Engineering and Applied Sciences 12(16):4186-4192. DOI: 10.3923/jeasci.2017.4186.4192. September 2017. Malaysia.

https://www.researchgate.net/publication/320148636_Determ inants_of_cloud_computing_adoption_at_firm_level_From_t he_technological_context

[12] Research Paper: The Importance of Business Model Factors for Cloud Computing Adoption: Role of Previous Experiences. Authors Kristina BogatajHabjan and Andreja Pucihar. Research Papers Number 3, August 2017. DOI: 10.1515/orga-2017-0013.

Slovenia https://www.dlib.si/stream/URN:NBN:SI:DOCPOG14CBC/e5181a84-15df-41b0-9c8e-8b6eb0f6be49/PDF

[13] Journal: Effects of Industry Type on ICT Adoption among Malaysian SMEs. Authors Khong Sin Tan ,Uchenna Cyri Eze, and Siong Choy Chong. IBIMA Publishing Journal of Supply Chain and Customer Relationship Management. Vol. 2012 (2012), Article ID 113797, 12 pages DOI: 10.5171/2012.113797. Malaysia http://ibimapublishing.com/articles/JSCCRM/2012/113797/1 13797.pdf

[14] Book: "Executive's Guide to Cloud Computing". Author Eric A. Marks Bob Lozano, Copyright \# 2010 by Eric A. Marks and Roberto R. Lozano. All rights reserved. Published by John Wiley \& Sons, Inc., Hoboken, New Jersey. Published simultaneously in Canada. 2010, p. 74-75. http://160592857366.free.fr/joe/ebooks/tech/Wiley\%20Execu tive $\% 27$ s\%20Guide\%20to\%20Cloud\%20Computing.pdf

[15] Paper: Cloud Computing Strategy Direction Paper. By the Department of Finance and Deregulation (DFD) Cloud Computing Strategic Direction Paper: Opportunities and 
applicability for use by the Australian Government, Version 1.1 (released April 2013). https://www.finance.gov.au/files/2013/04/final-

_cloud_computing_strategy_version_1.1.pdf

[16] International Conference: A Comprehensive Study On Cloud Computing. Authors Ab Rashid Dar and Dr. D. Ravindran. Conference: 1st International Conference on Recent Developments in Science, Humanities \& Management-2018. Volume No. 07. Special Issue No. 04. ISSN: 2319-8354. April 2018. https://www.researchgate.net/publication/324587212_A_CO MPREHENSIVE_STUDY_ON_CLOUD_COMPUTING

[17] Paper: Cutting Through The Fog: Understanding The Competitive Dynamics In Cloud Computing, BRIE Working Paper 190 (Beta) May 1, 2010 @C Copyright 2010. Authors Kenji E. Kushida, Dan Breznitz and John Zysman. USA. http://brie.berkeley.edu/publications/wp190beta.pdf

[18] Book: Handbook of Cloud Computing: Authors BorkoFurht and Armando Escalante. ISBN 978-1-4419-6523-3 e-ISBN 978-1-4419-6524-0 DOI 10.1007/978-1-4419-6524-0. USA, Published 2010 https://studytm.files. wordpress.com/2014/03/hand-book-ofcloud-computing.pdf

[19] Journal: International Journal of Engineering Science and Technology (IJEST). Security Issues In Cloud Computing And Countermeasures. Authors Danish Jamil and Hassan Zaki. Department of Computer Engineering, Sir Syed University of Engineering \& Technology, Main University Road, Karachi, Sindh - 75300, Pakistan. ISSN : 0975-5462 Vol. 3 No. 4 April 2011, Pg. 2672 - 2676. Pakistan. http://citeseerx.ist.psu.edu/viewdoc/download;jsessionid=DB E09AEFD8EFC1A16B367F8249DA4287?doi=10.1.1.640.44 $7 \&$ rep=rep 1 \&type $=$ pdf

[20] Article: Cloud Computing and Computing Evolution. Authors Markus Böhm,Stefanie Leimeister,Christoph Riedl,Helmut Krcmar. January 2011. from IEEE Xplore. 978-0-7695-3840-2/09 $\$ 26.00 \quad$ (C) 2009 IEEE. DOI 10.1109/CLOUD.2009.6. Germany. https://www.researchgate.net/publication/268011245_Cloud_ Computing_and_Computing_Evolution

[21] Dr.Ramnath K. Chellappa, Associate Professor \& Caldwell Research Fellow Doctoral Program Coordinator, Information Systems \& Operations Management, Room 407, 1300 Clifton Road, Goizueta Business School, Emory University, Atlantaa. GA 30322-2710. (DEFINITION IN SECTION: CLOUD COMPUTING)http://www.bus.emory.edu/ram/

[22] History of Cloud Computing Timeline. https://cdn2.hubspot.net/hubfs/620276/History_of_Cloud_Co mputing_Timeline.pdf?t=1488486871142

[23] Article: A Brief History of Cloud Computing. Author Keith D, Foote, 22 $2^{\text {nd }}$ June, 2017. USA. http://www.dataversity.net/brief-history-cloud-computing/

[24] Cloud Computing History, from Wikipedia. https://en.wikipedia.org/wiki/Cloud_computing

[25] PhD Theses: Implementing a Forensic Educational Package for Registered Nurses in Two Emergency Departments in Western Australia (Doctor of Philosophy (PhD). By Michel, C. M. (2008). University of Notre Dame Australia. https://www.google.co.uk/url? sa =t\&rct=j\&q=\&esrc=s\&sourc $\mathrm{e}=$ web $\& \mathrm{~cd}=2 \& \mathrm{cad}=\mathrm{rja} \& u a c t=8 \& \mathrm{ved}=0$ ahUKEwiZ3 -

W86vjXAhWqD8AKHfIzAiwQFgg0MAE\&url=http $\% 3 \mathrm{~A} \% 2$ F\%2Fresearchonline.nd.edu.au\%2Fcgi\%2Fviewcontent.cgi\% 3Ffilename\%3D9\%26article\%3D1030\%26context\%3Dthese s\%26type\%3Dadditional\&usg=AOvVaw2Br54FKxZf8KWH6XLfjZk

[26] Paper: Exploring the philosophical underpinnings of research: relating ontology and epistemology to the methodology and methods of the scientific, interpretive, and critical research paradigms. By Scotland, J. (2012). English Language Teaching; Vol. 5, No. 9; 2012 ISSN 1916-4742 EISSN 1916-4750 Published by Canadian Center of Science and Education. https://pdfs.semanticscholar.org/f24f/1d16645ee19b0263f4c3 77d9e086ed277a3c.pdf

[27] Book: Sociology (14th edition). Author John J. Macionis.
(2012). ISBN 10: 020511671X / ISBN 13: 9780205116713. New York: Pearson.

[28] Book: Research design: Qualitative, quantitative, and mixed methods approaches. By John W. [56]. Fourth edition, Copyright @) 2014 by SAGE Publications, Incorporated. file:///C:/Users/Raja\%20Ubaid.raja/Downloads/John\%20W. $\% 20$ Creswell-

Research\%20Design_\%20Qualitative,\%20Quantitative,\%20a nd\%20Mixed\%20Methods\%20ApproachesSAGE\%20Publications, \%20Inc\%20(2013)\%20(1).pdf

[29] Journal: A Primer in Survey Research. Author Suzanne C. Watson. The Journal of Continuing Higher Education, Winter 1998, pp. 31-40. Reproduced by permission of the Association for Continuing Higher Education, Inc. https://pdfs.semanticscholar.org/1059/1b5151e7da3f11dfea5a 3b0bf69fa7b14736.pdf

[30] Journal article: Systematic planning for using an online survey, Authors Lois A. Ritter and Valerie M. Sue. New Directions for Evaluation, Publisher: Wiley Subscription Services, Inc., A Wiley Company, Volume: 5 September 2007, Issue 115, ISSN:1097-6736, EISSN:1534-875X, DOI:, Copyright (C) 2007 Wiley Periodicals, Inc. http://onlinelibrary.wiley.com.ezproxy.wlv.ac.uk/doi/10.1002 lev.231/epdf 